\title{
Various Aspects of Bollard Pull Tests and Analysis of Test Results
}

\author{
Arun Kr Dev \\ School of Marine Science and Technology (MaST), Newcastle University International Singapore (NUIS), Singapore
}

\begin{abstract}
The static force exerted on a hawser at zero ship speed by a vessel, otherwise known as the bollard pull, is one of the key performance indicators of Tugs, Anchor Handling Tugs (AHTs) and Anchor Handling Tug Supply Vessels (AHTSVs). The value of bollard pull is considered critical as it defines the functionality and performance of the vessel. When a company decides on chartering a vessel, a definite prerequisite considered is the value of the bollard pull. The value may be obtained via three ways: calculations, model-testing, and full-scale trials. The latter is often used officially to certify the vessel's bollard pull rating, with the presence of the vessel's owners, surveyors, and any other third parties. The tests and trials follow a set of guidelines provided by classification societies but do not have a standardized set of rules. Therefore, disagreements often arise over the results of such tests and trials. Tests are often carried without any load cells measuring the shaft power to ascertain the brake horsepower (BHP). Simply, engine rpm/ rating is used to fix the $100 \%$ maximum continuous rating (MCR) which often in the range of $105-108 \%$ MCR. Some of the parties involved in certifying the correct bollard pull tests (BPTs) do not even understand what is all about the bollard pull. Everybody is looking for a higher figure for the bollard pull on the certificate when the reality is different. The author examines and discusses the broad spectrum of factors that affects the "true" value of the bollard pull and explains why such a standardized set of mandatory BPT and the trial code is deemed necessary. The author also presents some of the interesting BPTs data to show the differences in various ways of conducting BPTs.
\end{abstract}

Keywords: Bollard pull; test and trial code; tugs; offshore support vessels; AHTs; AHTSVs; shaft power; engine MCR; instrumentation; classification societies; vessel performance

\section{Introduction}

The bollard pull (BP) is the zero speed pulling/pushing capability of a vessel, i.e., Tugs, Anchor Handling Tug (AHTs), Anchor Handling Tug/ Towing Supply Vessel (AHTSVs), trawlers, etc. It is considered as one of the key practical performance indicators of the above-mentioned vessels, measuring the usefulness of the vessel in a stranding scenario or in holding large vessels such as tankers or towing a rig.

Such bollard pull tests (BPTs) are conducted to ensure the performance of the vessel upon delivery. The test is witnessed in the presence of the International Classification Societies (CS) surveyors

\footnotetext{
Manuscript received by JSPD Committee June 24, 2017; accepted July 20, 2017.

Corresponding author: Arun Kr Dev, akdev@singnet.com.sg; a.k.dev@ncl. ac.uk
}

representing the classification society, the owners' representatives of the vessel, engine and propeller manufacturer, representatives from the shipyard, and people who have partaken in the construction of the vessel. The BPTs have a significant impact on the performance indicator of Tugs, AHTs, and AHTSVs.

It is so because, often, ship owners/ship operators would use the value of the bollard pull certification as a selling point of the vessel. The higher the value, the higher the weight the vessel can tow. Therefore, the value of the bollard pull becomes a key performance indicator of the vessel. Bollard pull is critical to ship owners/ship operators so much, so that the value of the bollard pull is one of the contractual items to be met during the contractual delivery of the vessel.

However, there are no stringent rules stipulated by classification societies for the conduct of a BPT. What are given is usually recommended guidelines for the conduct of the test, which is not specific enough to provide a standardized and identical method of testing. 
Improper method of testing would result in inaccurate values of recording the bollard pull. Often, such values are overquoted. One such possibility of bollard pull being overquoted is when during the conduct of such tests, the engine maximum continuous rating (MCR) is set to more than $100 \%$, to obtain a higher value of bollard pull. Such scenarios might cause conflicts with operational safety such as the stability during towing and anchor handling. What is lacking right now in the industry, is that, is the measurement of the shaft horsepower (SHP) power to establish the brake horsepower (BHP) at $100 \%$ MCR. Certain terms must be defined properly, to formulate a standardized set of BPT procedure.

Firstly, it is important to understand the general procedure of a BPT and trial. A suitable test site is chosen, which is referred to as a basin, with a bollard pull testing facility. The bollard pull testing facility is certified to conduct BPTs and trials of up to a set value of bollard pull.

There would be two sections of the hawser: one of the sections connects the bollard and the dynamometer together, and the other section connects the dynamometer and the towing hook/towing drum, which is attached to the towing drum and winch, onboard the Tug/AHT/AHTSV.

Next, there would be different bollard pull terms used. Such terms should also be defined appropriately (Steerprop 2001):

1) Continuous Bollard Pull-it is the sustainable static pull with the vessel's engines, running at the engine maker's recommended MCR. The average value of the pull is taken over a specific period, usually from 5 to 10 minutes. If the readings are taken at 30-second intervals, the Continuous Bollard Pull is the average of all the readings over the specific period.

2) Maximum Static Bollard Pull-it will have a higher value than the Continuous Bollard Pull as it takes the highest value of the period of 30-second intervals. Subsequently, the highest average values of two consecutive periods are taken.

3) Maximum Bollard Pull-it is the single highest measured value, which is achieved when the engines are running at an overloaded condition (e.g., 110\% MCR) is achieved for very short periods without causing damage to the engines. It is significantly higher than the Continuous Bollard Pull and therefore should not be referred to as the usual "Bollard Pull."

\section{Aim and objectives}

There are two main aims. The article aims to assess critically the guidelines provided by different classification societies and to formulate a standardized set of general guidelines most suitable for the marine and offshore industry.

The other is the collection of data of BPTR and to analyze those data to find the various aspects of bollard pull test results (BPTRs).

To achieve the purpose, the following objectives are established:

1) to define the different types of bollard pull and describe how significant is the bollard pull value critical in the marine and offshore industry being used as a functionality indicator of a vessel.

2) to list and explain the different factors, (e.g., the propeller, the aft hull shape, etc.) that affect the value of the bollard pull.

3) to compare and identify the guidelines used by the classification societies used during the conduct of a BPT and hence, listing the commonalities and differences.

4) to do a research on the comparison of the guidelines used by the classification societies, and therefore, formulate a set of general guidelines mostly appropriate for the marine and offshore industry.

5) to produce a number of standard checklist documents, which are to be used during a BPT.

6) to collect data of full-scale BPTRs and categorize those data and analyze to see the bollard pull trend as well as an anomaly in different sets of measurements.

\section{Methodology}

For this subject, the targeted vessels are mostly Tugs, AHTs and AHTSVs. Such vessels go through the conduct of BPTs. A flowchart of how the aim of "How BPTs are done?" is achieved is shown in Fig. 1.

The key factors that affect the value of the bollard pull are first identified. Such factors include the propulsion power and propeller design, aft body hull form design and nozzle design. Adjustments and improvements can be done to the factors during the design stage of the vessel to ensure the optimal bollard pull value.

Several recognized bodies such as International Maritime Organization (IMO 1998) and International Towing Tank Conference (ITTC 2011) have their sets of guidelines, where the classification societies would then make certain changes to accommodate to their respective classification societies.

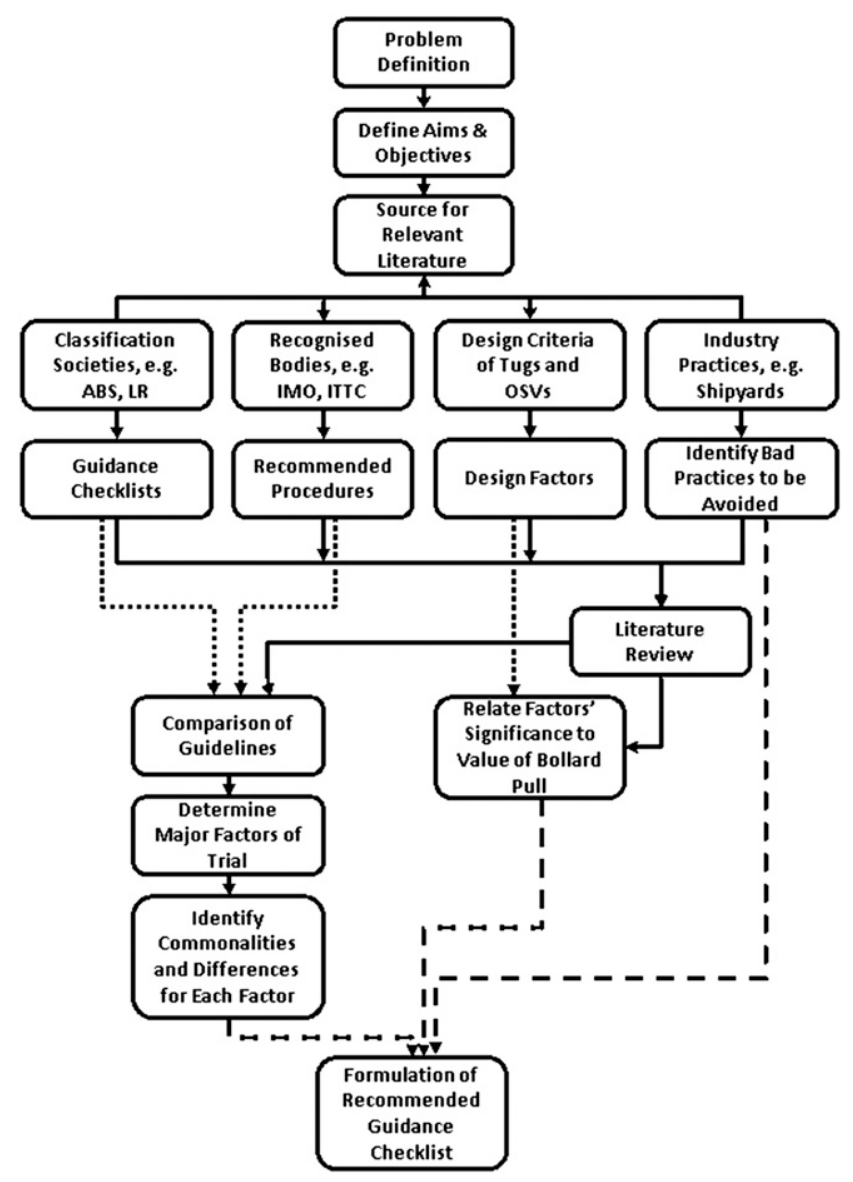

Fig. 1 Work plan flowchart 
Shipyard practices are also noted. Each shipyard would have slightly different procedures as compared with the rest. Such differences might be slight, but it might be critical to the reliability of the accuracy of the test results.

British Ship Research Association (BSRA 1965) published a Code of Procedure for Bollard Trials of Tugs, which stated the high importance of preparation and calibration for the test, where failure to comply would significantly affect the results of the bollard pull.

Guidelines from major CS are also obtained. Such guidelines provide a comparison between different classification societies. The above differences and similarities are tabulated in the table for easy comparison and referencing.

Noting the key factors in performing a BPT, the detailed formulation for each factor is done to ensure a close to an ideal test is performed. The formulation was then compiled.

With the above steps performed, the final wording of guidelines in the form of guidance checklist recommended for use for BPTs and trials can then be formulated accordingly so as to provide a safe yet accurate procedure for testing.

\section{Definition of bollard pull}

The bollard pull of a vessel is defined as the tractive force of a Tug, which can be expressed in metric tonnes (tonne) or kilo Newtons (kN) (Zahalka 2012).

The test is conducted at zero forward speed; therefore, the wake $(w)$ and relative rotative efficiency $\left(\eta_{R}\right)$ do not apply. It is only the thrust deduction coefficient $(t)$ that accounts for the interaction with the hull of the vessel.

At zero forward speed, the propeller would induce high axial and tangential velocities. This results in the flow through the propeller disc to be accelerated and thus creating a strong current, a heavy loading for the propeller and rudder.

Sometimes, the propeller may cavitate as ventilation occurs and the air is sucked in from the free surface. When this happens, the value of the bollard pull would, therefore, be inaccurate (ITTC 2011).

Simple rules have been used to relate the value of the bollard pull to the power installed on the vessel as estimations. Such approximations (Zahalka 2012) for the calculation of the bollard pull from the BHP of a Tug are given as

Fixed Pitch Pr opeller: (Free Wheeling) $=\frac{\mathrm{BHP} \times 0.9 \times 1.10}{100}(t)$

Fixed Pitch Pr opeller and Kort Nozzle $=\frac{\text { BHP } \times 0.9 \times 1.20}{100}(\mathrm{t})$

Controllable Pitch Pr opeller:(Free Wheeling)

$$
=\frac{\mathrm{BHP} \times 0.9 \times 1.25}{100}(\mathrm{t})
$$

Controllable Pitch Propeller and KortNozzle

$$
=\frac{\mathrm{BHP} \times 0.9 \times 1.40}{100}(\mathrm{t})
$$

Where BHP is at $100 \% \mathrm{MCR}$
The values that are obtained from the above approximations are to be regarded as rough estimates. This is because, with different propulsion systems, a different bollard pull can be achieved, even with identical engines with the same installed power.

The value of bollard pull is usually used as a performance indicator of a particular vessel. Therefore, the initial calculation of the bollard pull of a vessel should not differ too much from the value obtained during the full-scale test of the same vessel.

The value of bollard pull also helps 1) to calculate the preplanned towing speed, and 2) to provide sufficient power-reserve to ensure the safety of the tow when in unfavorable weather conditions.

\section{Design factors affecting BP}

The design of a Tug, AHT, and AHTSV is not only dependent on the different physical components, such as the propellers, rudders, and engines. The performance is also influenced by the interaction between the various elements. An example would be the interaction between the propeller and the nozzle.

From Fig. 2 (Nielsen 2010), it can be observed that the attainable value of the bollard pull heavily depends on power density. To achieve the optimal value of the bollard pull, the value of the power density should be as low as possible. To attain a low-power density, the diameter of the propeller should be designed such that it is the widest that the vessel is able to accommodate, and it is fully submerged in water in ballast condition.

To achieve a high bollard pull, the vessels are usually fitted with twin screw with ducted controllable pitch propellers. It also gives them great maneuverability. It must also be understood that the installed power is not the only determinant that affects the value of bollard pull, where factors such as an optimized propulsion system and hull form design would also create an impact on the value of the bollard pull. Several design factors influence the value of the bollard pull which would be discussed.

\subsection{Propulsion power and propeller design}

The propellers are usually chosen by deciding on the power of the vessel, as the horsepower is proportional to the propeller diameter. Based on the expected operating conditions and propulsion power of the vessel, the diameter and the blades of the propeller are then designed appropriately.

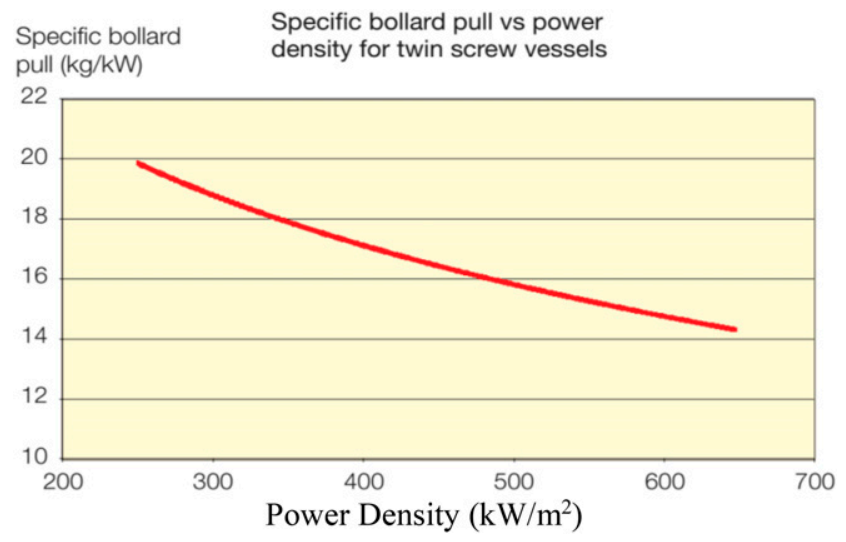

Fig. 2 Specific bollard pull versus power density 
Factors such as the diameter of the propellers and r.p.m. of the shaft would affect the choice of a propulsion system used, as cavitation is a significant issue to be considered during the design of a propulsion system, specifically the propellers. For such Tugs and offshore support vessels, these are usually fitted with twin screw propulsion systems.

Factors such as open water propeller efficiency, cavitation, and vibration of the propeller are to be considered during the design of the propeller. The interaction between the nozzle and propeller are also critical during the design of the propeller. For most vessels that require maximum bollard pull, the shape of the blades tends to have wider chords at the tip of the propeller's blades, as shown in Fig. 3 (Lytewater 2009).

The skew of the propeller is also a defining factor for the design of the propeller. Given the right skew angle, the noise and vibration induced by the propeller can be suppressed.

\subsection{Aft body hull form design}

The water flow to the propeller, i.e., the wake field is influenced by the aft body hull form design. The lines of the aft hull form would, therefore, influence the thrust deduction coefficient.

$$
t=1-\frac{T_{\mathrm{BP}}}{T_{\mathrm{PB}}+T_{\mathrm{NB}}}
$$

Where, $t$ is the thrust deduction factor, $T_{\mathrm{BP}}$ is the thrust of the bollard pull, $T_{\mathrm{PB}}$ is the propeller thrust in behind condition, and $T_{\mathrm{NB}}$ is the nozzle thrust in behind condition.

It can be seen that if the value of the thrust for the propeller and nozzle is reduced because of the thrust deduction coefficient, this will result in the thrust of bollard pull to be reduced too. It is caused by the interaction between the propeller and the nozzle, and the hull surfaces near to those.

To minimize the thrust deduction factor, proper design of the aft hull lines should be done. The shaft that the propeller is attached to should also be increased to the maximum wherever possible. It would then reduce the value of the thrust deduction factor to a minimum.

It should be noted that the wake coefficient for the design is also an important factor. However, because of the conduct of the BPT at zero speed, there is no effect of wake present.

\subsection{Propeller nozzle design}

A nozzle is a propeller shroud encircling just outside the propeller's tips. Including a nozzle in the design of the vessel would

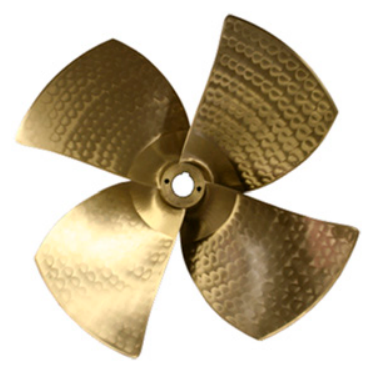

Fig. 3 Kaplan propeller increase the thrust produced by the propeller. The effect of the nozzle is based on the hydrodynamics effect of pressure and velocity, where the thrust of water that passes through the nozzle is accelerated further.

Alignment of the nozzle during installation is also critical as it would affect the bollard pull. Nozzle alignment requirements would reduce the risk of misalignment during the installation process.

\section{Key factors affecting BPTs}

To ensure that the vessel achieves the optimum performance during a BPT, several factors are to be noted when conducting a test.

In an ideal (imaginary) BPT (Dev 2013), the following criteria are to be met:

1) lower and straight hawser (no sag and no angle)

2) larger water depth (three to four times draught with a minimum of $50 \mathrm{~m}$ or more).

3) minimal current $(<0.5$ knots $)$

4) minimal wind $(<0.5 \mathrm{~m} / \mathrm{s})$

5) good trim and sufficient draught for propeller immersion

Therefore, the key factors that affect the BPT are then determined:

1) environment

2) measurement and instrumentation

3) vessel condition

The BPT is supervised by the surveyors of CS, which then certify the vessel, the value of the measured bollard pull.

However, the guidelines of the classification societies differ in various ways. Therefore, the comparison is made between the guidelines stipulated by the different classification societies.

The different classification societies that would be used in the comparison later would include:

1) American Bureau of Shipping (ABS)

2) Bureau Veritas (BV)

3) Det Norske Veritas (DNV)

4) Germanischer Lloyd SE (GL)

5) Lloyd's Register (LR)

6) Registro Italiano Navale (RINA)

It is to be noted that although DNV and GL have recently merged to form DNV-GL, the guidelines are obtained prior from individual classification societies for comparison purposes. The comparisons for each factor stated above are then tabulated in a tabular form in Appendix A.

\subsection{Environment}

BPTs are usually conducted in areas where dock walls are present. With the presence of dock walls, the propeller wake from the propeller/s would cause a buildup of circulation. This buildup of circulation would result in a maximum bollard pull obtained too early in the course of the test, and drop when the test is prolonged. Such BPTRs obtained would not be an accurate representative of the service condition of the vessel, as the vessel would not remain in a particular position for such a long period of time to create such a significant amount of circulation during operation.

To reduce the impact of circulation on the effect of the BPTRs, the position of the vessel should be placed such that it is clear of any 
walls, and the propeller wake is given a clear run. RINA (2011) recommends the vessel to be positioned at $60^{\circ}$ in respect to the pier. An example of such position is where the wake can run to either side of the bollard as shown at A of Fig. 4.

Results of model-tests (BSRA 1965) have shown that the influence of the dock wall is reduced when the depth of water is increased. Therefore, it should be known that the deeper the water, the results of the BPT would be more accurate. The distance between the vessel's stern and the dock wall should, therefore, be adequate if the available depth of water is limited.

Further positions for a BPT can be observed in Fig. 5.

Various classification societies including DNV (2011), RINA (2011) and GL Noble Denton (2010) further recommend that the distance should not be less than $100 \mathrm{~m}$. The additional length of the hawser should be considered as the position of the towing hook on the vessel which would influence the total length of the hawser. The inclination of the hawser between the bollard and the towing hook should be kept to a minimum so that the horizontal component of the pull would then be measured accurately by the load cell.

BPTs are to be carried out in calm weather to reduce the effects of currents and winds as this would cause errors in the measurements. However, ABS (2012) allows the possibility of using correction due to bad weather conditions. It should not be allowed as the test would provide erroneous results.

It should be noted that the maximum value is recorded when the hawser is directly over the vessel's stern. The vessel would yaw upon the conduct of the test, and the angle of yaw becomes excessive, it would cause a considerable drop in the value of the pull. In such cases, the test should be repeated, with the angles of yaw recorded.

To ensure that the hawser is safe for use, it should be provided with a certificate, stating the breaking strength, material, and other relevant particulars of the hawser. Attached to the hawser includes equipment such as the winch and the towing hook. Such equipment should also be provided with a certificate to facilitate the conduct of the test.

During the conduct of the BPT where the vessel starts to sheer violently, it may cause a high pull value, in which the measured values should be ignored. Then the tests need to be repeated for accurate results.

\subsection{Measurement and instrumentation}

It must be noted that the conditions of the BPTs are unlikely to produce readings that are completely steady. In this case, there is a need to obtain mean values for analysis.

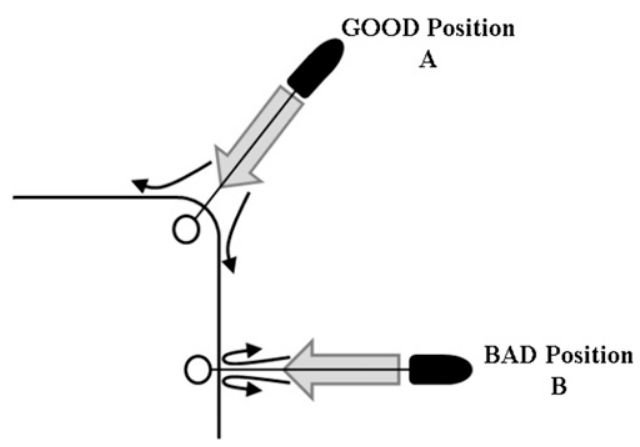

Fig. 4 Good and bad positions for a BPT

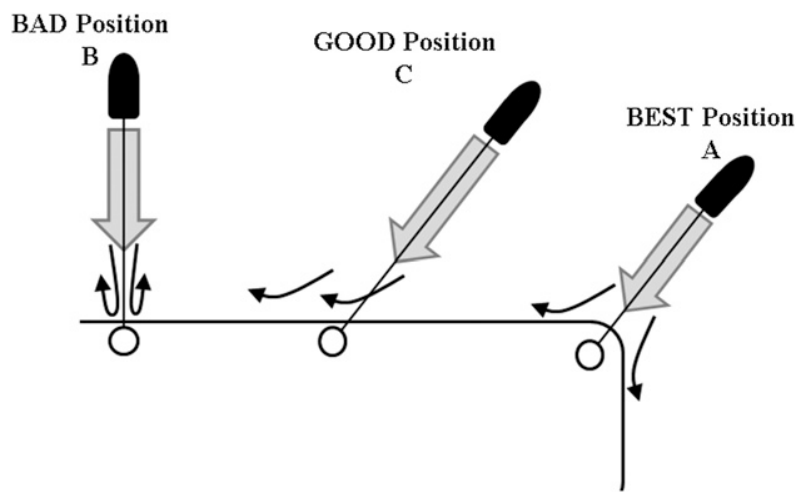

Fig. 5 Best, good, and bad positions for a BPT

The measuring instrument can either be a mechanical or an electrical load cell. Furthermore, the load cell must be provided with a calibration certificate, as requested by all classification societies conducting the test. It would then be ideal to provide the calibration being performed in the horizontal position because of the nature of usage during the test. The accuracy of a load cell differs for different classification societies.

An autographic recorder is to be included during the conduct of the test, as seen in the comparison in Appendix A. The recorder would then be able to produce the continuous record of the pull. It would make the analysis of results more accurate. However, if it is not possible to provide one, BV (1986) and GL Noble Denton (2010) recommend consecutive readings to be taken at 20 and 30 seconds, respectively.

The bollard pull should be taken on the vessel's towing hook, with the load cell located either next to the towing hook or near the bollard ashore (later preferable).

If the load cell is placed near the bollard ashore, arrangements should be made for the movement of the load cell for it to move freely. It would then allow alignment between the cable and the load cell in the event when the vessel sheers from one side to another. It would, therefore, ensure that the load cell measures only the horizontal component of the pull. An example of such provision would be mounting the load cell on a trolley as shown in Fig. 6 (BSRA 1965).

It is necessary to obtain the power developed by the shaft that corresponds to the respective value of bollard pull. A torsionmeter should be utilized to obtain the shaft power. By adding the considerable losses during transmission and the shaft power, it should give an appropriate value of the engines' BHP @ 100\%

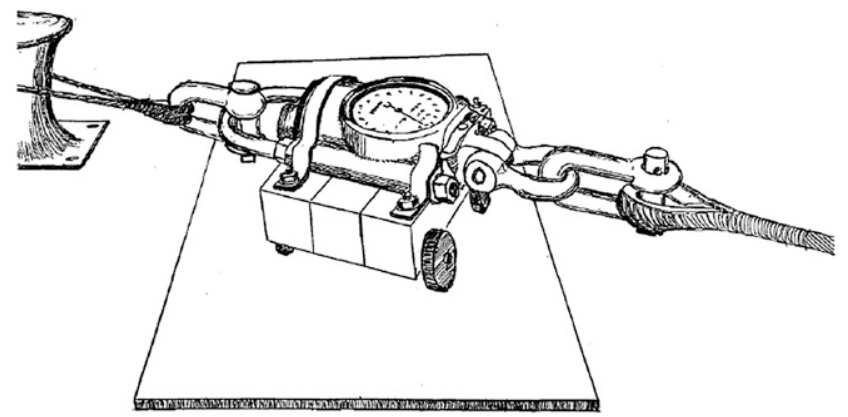

Fig. 6 Load cell mounted on trolley for alignment with cable 


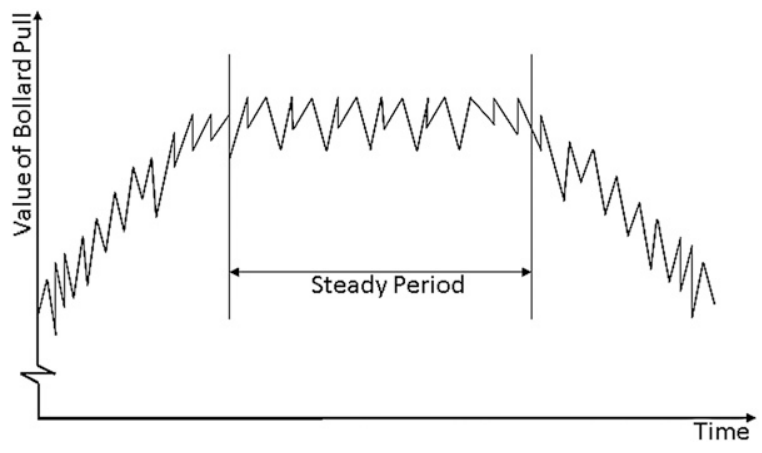

Fig. 7 Graph of value of bollard pull against time

MCR, which should be at $100 \%$. It should therefore ensure that the engine is running at the manufacturer's recommended rated power at $100 \%$ MCR.

\subsection{Vessel condition}

The vessel condition is expected to be in the same condition during the normal operation. Therefore, the requirements comprise of conditions of the vessel during normal operation.

The condition of the vessel is also critical in the conduct of the BPT. The vessel must be evenly keeled or trimmed to intended normal operations during the conduct of the test. It is also recommended that the vessel is ballasted to the condition where it is supposed to operate.

The rudder angle must be kept to zero during the entire test, as any steering that will result in a drop is BPTRs. Equipment used during the test should also be the same during the use of actual service. It must be noted that any auxiliary equipment driven by the main engine(s) or propeller shaft(s) during normal operations should also be connected during the test.

All classification societies require that the main engine(s) should be running at a manufacturer's recommended MCR and should not be exceeded. ABS (2012) recommends that the engine temperatures are maintained steady during the test.

Communication between the party onshore and the party onboard the vessel should be present. This form of two-way communications should be reliable and consistent, by means of possibly very high frequency (VHF) radio or a telephone connection.

\section{Analysis of BPTRs}

Given that the results are recorded continuously using an autographic recorder, the results would be similar to the graph as seen in Fig. 7. It can be observed that there is an initial increase in values, during the build-up of engine revolutions, followed by a period where the results reach a plateau and steady, and finally a drop because of the circulation of water induced by the stagnant position of the vessel.

The steady period as seen in Fig. 7 indicates that there is a repetitive oscillations occurring. This period usually lasts from 10 to 20 seconds. The oscillations are mainly caused by the movements of the rudder for keeping the vessel in her position.

If the test is done without an autographic recorder, continuous monitoring should be observed, and values of the maximum and minimum pull should be recorded every 30 seconds. The values of the results are to be recorded in a tabular form as shown in Table 1, as part of the report. Note that the last column of the table requires the mean pull value for previous 10 readings, in other words, an average of 5 minutes is taken.

As stated by BSRA (1965), it is recommended to plot the values of the Mean Bollard Pull against the value of the engine revolutions squared correspondingly, as shown in Fig. 8.

As the torque coefficient for the propeller remains constant for $100 \%$ slip, the results would be proven consistent if the points plotted are lying approximately in a straight line, and the line should pass through the origin of the graph.

\section{Data analysis of BPTs}

To carry out various investigations about the actual BPTRs, a set of measured data (a sample of 86 numbers of tests) is used. The list is shown in Table 2. The names of the vessel have been replaced with arbitrary serial numbers. The list also shows the installed power in $\mathrm{kW}$ and the measured ahead bollard pull in tonnes.

\subsection{Measured data and their analysis}

The purpose of data analysis of the BPTRs is to furnish some guidelines based on actual measurements on full-scale tests, which are seldom available in literature. Such analyses and their outcomes help in preliminary estimation of the bollard pull of a vessel. The data analyses of results provide the following mainly:

1) a simple preliminary mathematical relation between the installed propulsion plant and the expected bollard pull.

2) a proof of generally higher bollard pull, when the BHP is based on engine rating (normally greater than $100 \%$ MCR) instead of establishing it through shaft power measurement.

3) an alternative mathematical relation using the specific bollard pull and the power density, which also takes into account the propeller diameter in predicting the bollard pull.

4) a rule of thumb that 100 BHP produces a bollard pull of about 1.25 tonnes is approximately verified.

Table 1 Record of BPTRs in a tabular form

Bollard pull (Tonnes)

Time of day (hours, minutes, seconds)

Maximum

Minimum

Mean

Mean pull for previous 10 readings 


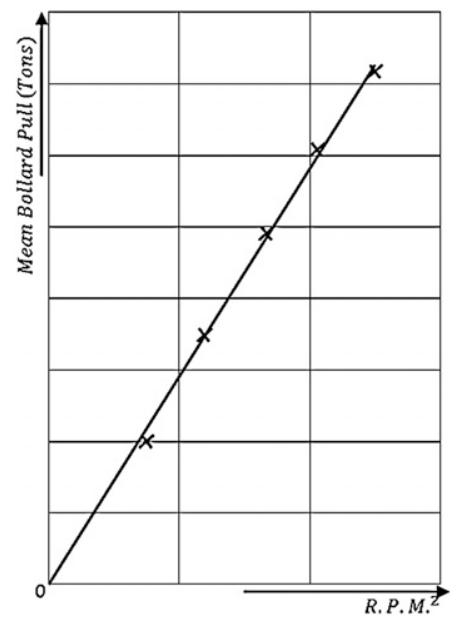

Fig. 8 Graph of mean bollard pull against R.P.M. ${ }^{2}$

5) the astern bollard pull is always less than the ahead bollard pull, i.e., Astern $\mathrm{BP} \approx(0.8$ to 1.0$)$ x Ahead $\mathrm{BP}$ for vessels with aft azimuth propulsion drives.

In Fig. 9, it has been shown that it is quite likely that the relation between the measured bollard pull (tonnes) and the brake power $(\mathrm{kW})$ shows an excellent linear fit with $r^{2}$ value almost equal to 0.98 showing the slope of about 0.162 . In Fig. 10, an interesting difference is noted for the same set of data. Now the data are separated into two groups: one data where the shaft power is measured to find the BHP after adding the losses in bearings, gearboxes, etc. and the other set of data is where the shaft power is not measured; the BHP is just based on the engine rating. The practice of doing the latter in BPT is becoming a standard practice in most of the shipyards in South Asia, Southeast Asia, and East Asia. There could be a euphoric agenda here among all parties to achieve a maximum bollard pull number (gimmick or illusion) on the certificate. The BHP rating is used as $100 \%$ MCR, but in reality, it is much higher almost in the range of around 104-106\% MCR. Surprisingly, the CS is not taking any serious note of it. The author cannot understand how one can calculate $100 \%$ MCR without having a proper shaft power measurement device. There are two main reasons for not doing it. The first reason is to save the cost of hiring a consultant to set up the shaft power measurement system, and the second reason is to achieve a so-called 100\% MCR BHP. However, the industry is bit naïve without understanding the farreaching implications of such a bollard pull number which will never be able to achieve in reality. Such practice of BPTs without shaft power measurement must not be accepted by any classification society so as not to jeopardize the operational safety of the vessel.

Figures 11 and 12 show the specific bollard pull (the bollard pull measured in $\mathrm{kg}$ divided by the total installed BHP in $\mathrm{kW}$ ) as a function of power density (the installed BHP divided by the disc area of the propeller connected to the engine or a pair of engines). These graphs were produced to see the similar trend as shown in Fig. 2. Although Figs. 9 and 10 could give an indication of bollard pull based solely on the installed BHP, Figs. 11 and 12 will be more relevant and practical to use because it will take into account the effects of the propeller diameter along with the installed power on the expected bollard pull. It could be a better way of preliminary estimation of the bollard pull of a vessel. The author
Table 2 List of vessels, bollard pull and installed power in kW

\begin{tabular}{|c|c|c|c|c|c|}
\hline Number & Col. 1 & Col. 2 & Number & Col. 3 & Col. 4 \\
\hline 1 & 40.2 & 2240 & 44 & 156.0 & 9000 \\
\hline 2 & 49.2 & 2998 & 45 & 124.0 & 8120 \\
\hline 3 & 49.2 & 2998 & 46 & 124.0 & 8120 \\
\hline 4 & 51.5 & 2998 & 47 & 81.7 & 4920 \\
\hline 5 & 49.5 & 3132 & 48 & 122.0 & 8120 \\
\hline 6 & 49.4 & 3132 & 49 & 56.6 & 3730 \\
\hline 7 & 51.0 & 3000 & 50 & 125.0 & 8120 \\
\hline 8 & 51.9 & 3000 & 51 & 124.0 & 8120 \\
\hline 9 & 35.8 & 2090 & 52 & 45.3 & 2646 \\
\hline 10 & 198.0 & 13440 & 53 & 45.3 & 2646 \\
\hline 11 & 35.6 & 2500 & 54 & 99.4 & 5940 \\
\hline 12 & 213.0 & 13440 & 55 & 101.0 & 5940 \\
\hline 13 & 212.0 & 13440 & 56 & 177.0 & 11040 \\
\hline 14 & 98.0 & 5850 & 57 & 63.2 & 5280 \\
\hline 15 & 211.0 & 13440 & 58 & 178.0 & 11040 \\
\hline 16 & 209.0 & 13440 & 59 & 135.0 & 8000 \\
\hline 17 & 61.5 & 3700 & 60 & 142.0 & 7920 \\
\hline 18 & 60.4 & 3700 & 61 & 135.0 & 8000 \\
\hline 19 & 98.7 & 5850 & 62 & 113.0 & 5940 \\
\hline 20 & 212.0 & 13440 & 63 & 139.0 & 7920 \\
\hline 21 & 61.3 & 3700 & 64 & 44.8 & 2646 \\
\hline 22 & 68.0 & 4924 & 65 & 43.1 & 2646 \\
\hline 23 & 66.8 & 4140 & 66 & 141.0 & 7920 \\
\hline 24 & 64.9 & 4140 & 67 & 140.0 & 8000 \\
\hline 25 & 68.2 & 4140 & 68 & 143.0 & 7920 \\
\hline 26 & 52.6 & 3530 & 69 & 135.0 & 8000 \\
\hline 27 & 166 & 9840 & 70 & 50.8 & 2998 \\
\hline 28 & 45.5 & 2646 & 71 & 51.5 & 2998 \\
\hline 29 & 46.3 & 2646 & 72 & 110.0 & 6972 \\
\hline 30 & 158.0 & 9840 & 73 & 150.0 & 9000 \\
\hline 31 & 100.0 & 6400 & 74 & 150.0 & 9000 \\
\hline 32 & 72.0 & 5372 & 75 & 141.0 & 7920 \\
\hline 33 & 141.0 & 9000 & 76 & 126.0 & 8190 \\
\hline 34 & 159.0 & 8700 & 77 & 60.1 & 5280 \\
\hline 35 & 45.5 & 2646 & 78 & 63.2 & 5280 \\
\hline 36 & 45.0 & 2646 & 79 & 135.0 & 7920 \\
\hline 37 & 135.0 & 8000 & 80 & 162.0 & 10736 \\
\hline 38 & 45.6 & 2646 & 81 & 112.0 & 5940 \\
\hline 39 & 44.8 & 2646 & 82 & 25.6 & 2424 \\
\hline 40 & 136.0 & 8000 & 83 & 68.9 & 4000 \\
\hline 41 & 71.4 & 4414 & 84 & 71.2 & 4000 \\
\hline 42 & 72.8 & 4414 & 85 & 110.0 & 5940 \\
\hline 43 & 43.5 & 2646 & 86 & 156.0 & 9000 \\
\hline
\end{tabular}

Col. 1 and Col. 3 = ahead bollard pull in tonnes.

Col. 2 and Col. 4 = installed brake power in kW.

himself has experienced before. Once for an AHTSV, there should have been an easy target of getting 70 tonnes out of 5916 BHP, but it was a problem because the propeller diameter was not suitable rather undersize. An increase of another $100 \mathrm{~mm}$ would have a better sign, but sometimes, the commercial people do not listen to save cost and invite unnecessary risks.

It is more or less an industry practice in bollard pull community that for a given power in BHP with an appropriately designed propeller, 100 BHP produces a bollard pull of about 1.25 tonnes, i.e., a standard bollard pull coefficient (t/100HP) $\left(\mathrm{BPC}_{100}\right)$ as $1.25 \mathrm{t} / 100 \mathrm{HP}$. Based on the collected data, one of the analyses was done to verify this standard practice/rule of thumb. From Fig. 13, it is clearly seen that after analyzing all data; the 


\section{Ahead BP vs BHP @ 100\% MCR}

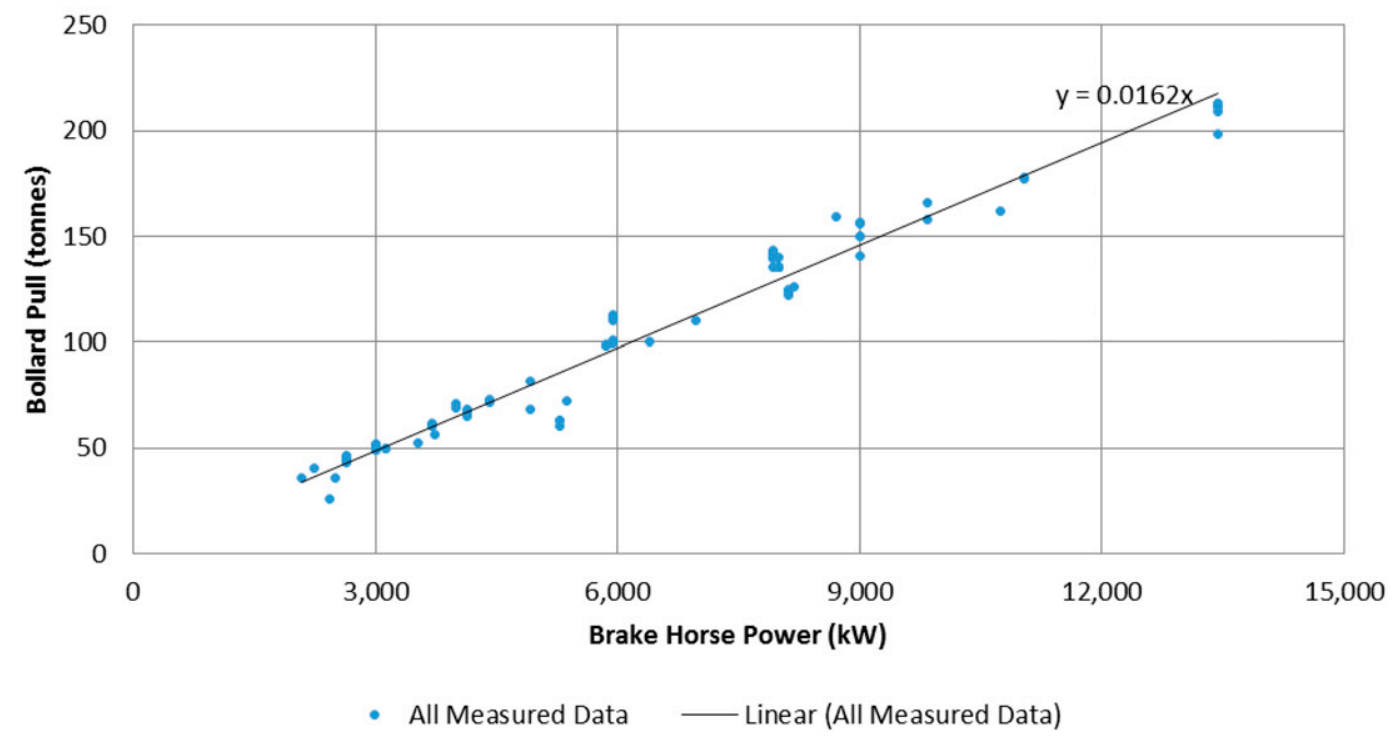

Fig. 9 Ahead bollard pull versus BHP at 100\% MCR

mean curve is somewhat less than 1.25 tonnes per 100HP line (red color), i.e., a $\mathrm{BPC}_{100}$ of 1.21 tonnes/100HP. The measured data are again found above and below the datum line of 1.25 tonnes per 100HP. Hence, in Fig. 14, two lines were then drawn for data greater than 1.25 tonnes and for data less than 1.25 tonnes. These two lines now provide a reasonable range of the estimated bollard pull roughly between $\mathrm{BPC}_{100}$ of 1.21 to 1.27 tonnes per $100 \mathrm{HP}$ which result in an average of $\mathrm{BPC}_{100}$ as 1.24 tonnes per $100 \mathrm{HP}$. So, the industry thumb rule/practice of using 1.25 tonnes per $100 \mathrm{HP}$ is somehow a justified value. In these two graphs, the author did not separate the bollard pull measured data based on whether the shaft horse power measured or not during the BPT. A larger data sample will only make all these statistical forecasts more accurate predictions.
In Figs. 15 and 16, some results of ahead and astern bollard pull measured data have been analyzed. From Fig. 15, it is observed that the measured astern bollard pull is always less than the ahead bollard pull except a few data where some opposite trends are noted. There could be some other reasons for having such few discrepancies. The astern bollard pull is always less than the ahead bollard pull except for thrusters which are below the baseline where both ahead and astern pull should always be the same theoretically as there is hardly any thrust deduction factor, e.g., for a tractor tug with two azimuth thrusters in front of the tug below the hull.

In Fig. 16, again the ratio of astern bollard pull to ahead bollard pull has been shown. It should remain theoretically below or equal

\section{Ahead BP vs BHP @ 100\% MCR}

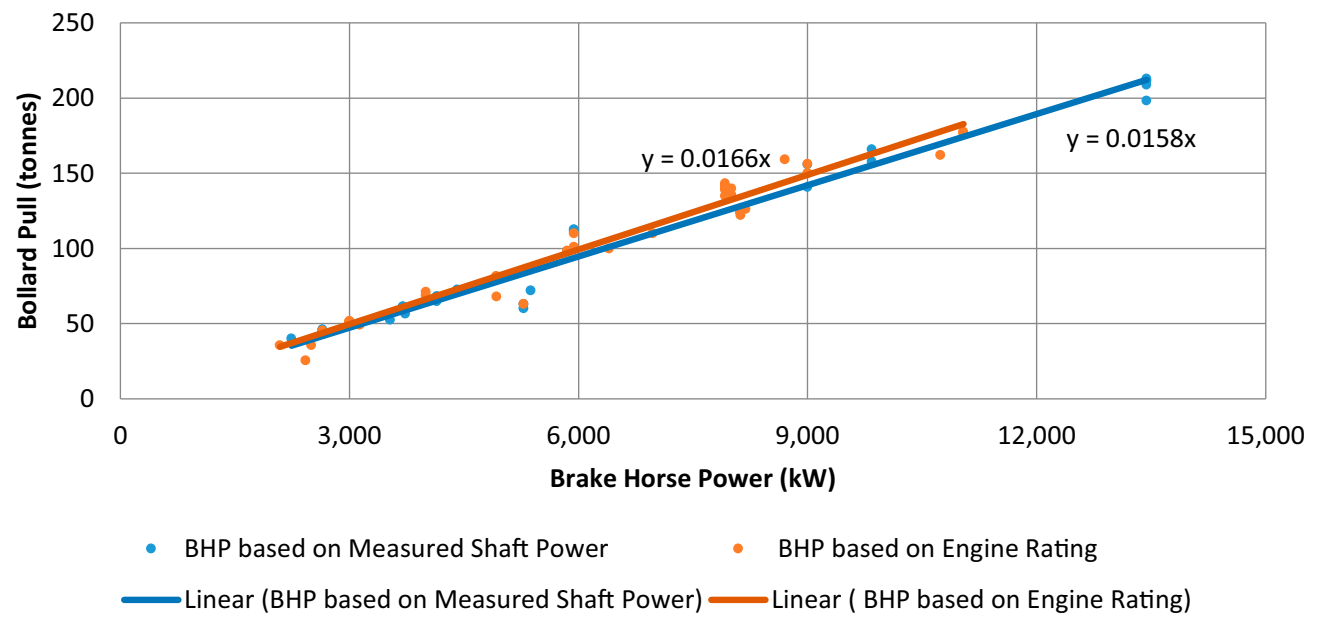

Fig. 10 Ahead bollard pull versus BHP at 100\% MCR 


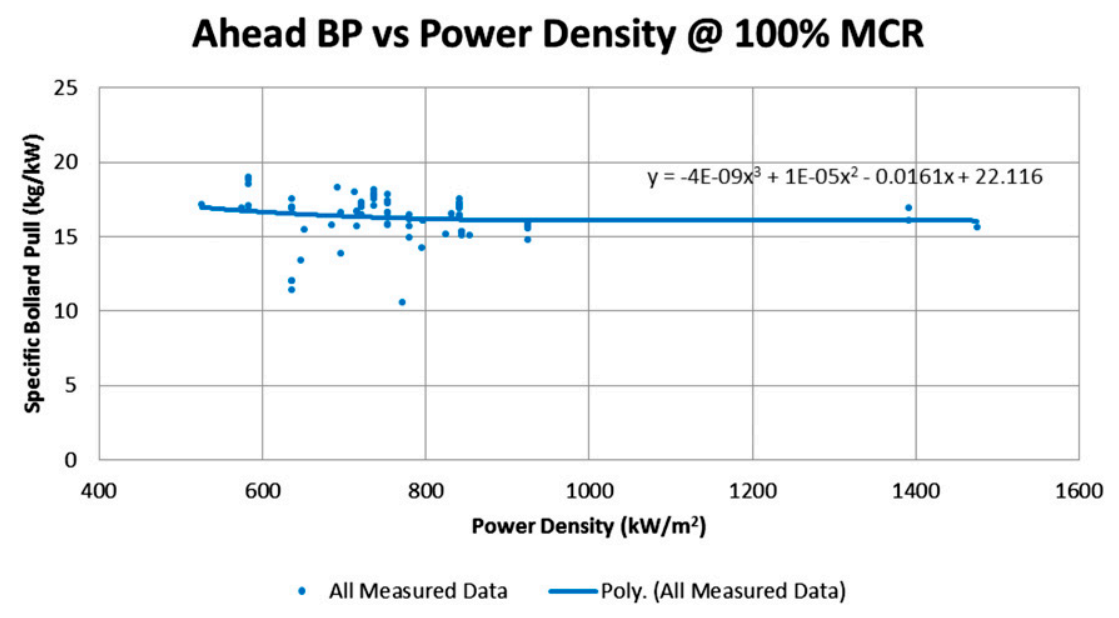

Fig. 11 Ahead bollard pull versus power density at 100\% MCR BHP

to 1 but because of discrepancies in some measured data, some values are seen to be more than 1 . It is clearly observed that the ratio varies from 0.8 to 1 . For vessels, mainly tugs with azimuth stern drive, the value will be close to 1 if most of the thruster is below the baseline. However, if the thruster is above the baseline, the astern pull will be less and can be said around 0.8 times the ahead bollard pull. For vessels like AHTSVs, the astern bollard pull is almost 0.4 times the ahead bollard pull. It is mainly because of Controllable Pitch Propeller (CPP) propulsion with rudders behind.

\section{Discussion}

Upon comparison of the guidelines of the stated classification societies, critical parts of the rules are identified. The tabulated comparison of the directives/guidelines can then be found in Appendix A. The adoption and formulation of the standardized set of BPT code is found in Appendix B

A typical BPTR should then be provided to certify the vessel of the bollard pull value. Critical information and particulars are to be provided in the report. A set of recommended format is provided in Appendix C. The report is to be attached with the various forms used by the surveyors to record data during the test.
Required documents such as calibration certificate of the load cell and engine manufacturer recommendations for $100 \% \mathrm{MCR}$ are also to be attached with the report upon submission to a classification society for verification.

Forms are created to provide convenience for surveyors for conducting the test. These forms can be found in Appendix D and E, where the forms are to be used for the engineers/surveyors onshore and on board the vessel, respectively.

Results have also shown that using a general rule to link the value of bollard pull to installed power would be very much inaccurate. It is because even with identical propulsion systems, vessels with different hull lines and propeller geometry would result in significant bollard pull results.

It is possible to estimate bollard pull, using numerical calculations or even model-testing, regardless of its accuracy. However, verifying the values of bollard pull is only certifiable by the classification societies by the means of full-scale testing.

To provide fair testing results, a uniform set of rules is to be used throughout all classification societies. In this connection, International Association of Classification Societies (IACS) can play a major role. Bollard pull is a performance very much related to the safety of operation like towing, anchor handling, etc. A wrong (misleading) bollard pull number on a certificate

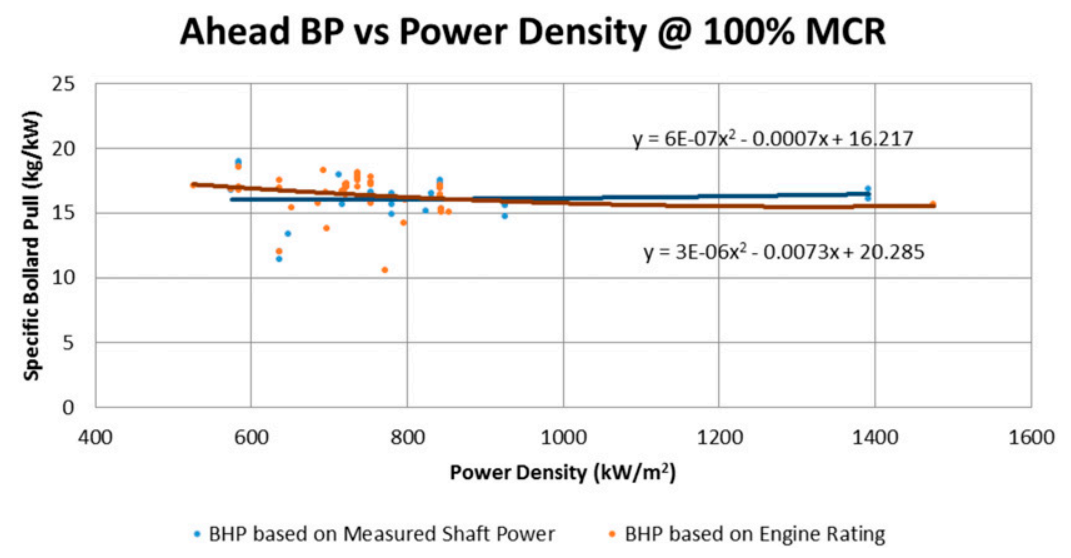

Fig. 12 Ahead bollard pull versus power density at 100\% MCR BHP 


\section{Ahead BP Coefficient @ 100\% MCR}

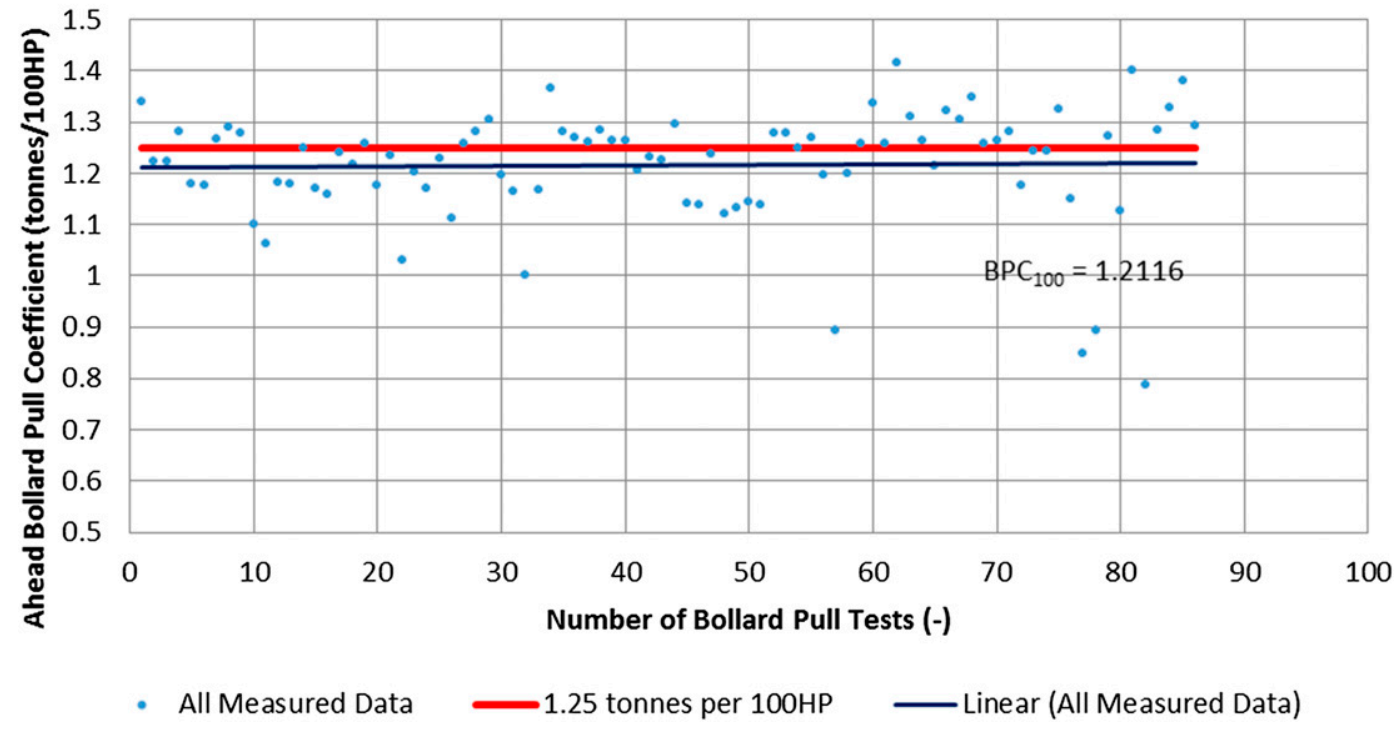

Fig. 13 Ahead bollard pull coefficient at 100\% MCR BHP

can lead to a potential danger in real operational life of the vessel.

It is a practice for companies that conduct BPTs to use corrections upon experiencing poor weather conditions. However, such corrections are not allowed and would result in an inaccurate value of bollard pull. Therefore, this should not be allowed as it would compromise the stability of the vessel if the vessel were to operate beyond its capability. It would result in a breach of operational safety leading to unnecessary risks.

The data analysis of the regular BPTs indicates that some of the industry practices are entirely valid. It also suggests that conducting a test without the shaft power measurement and alternatively setting a $100 \%$ MCR number based on engine rating is either a gimmick or an illusion to the parties involved. The truth is that such bollard pull number on a CS certificate is entirely not factual. The shipyard, the owner and the CS surveyor should exercise a right spirit of accuracy and quality in conducting/witnessing such an important test which should establish an unbiased fact (reality).

\section{Conclusions}

Directives/guidelines are being provided across most notable classification societies.

However, it has been observed that the guidelines as recommended in the CS's guidelines are not as definitive as it should be. It might thus cause the results of the bollard pull to be erroneous.

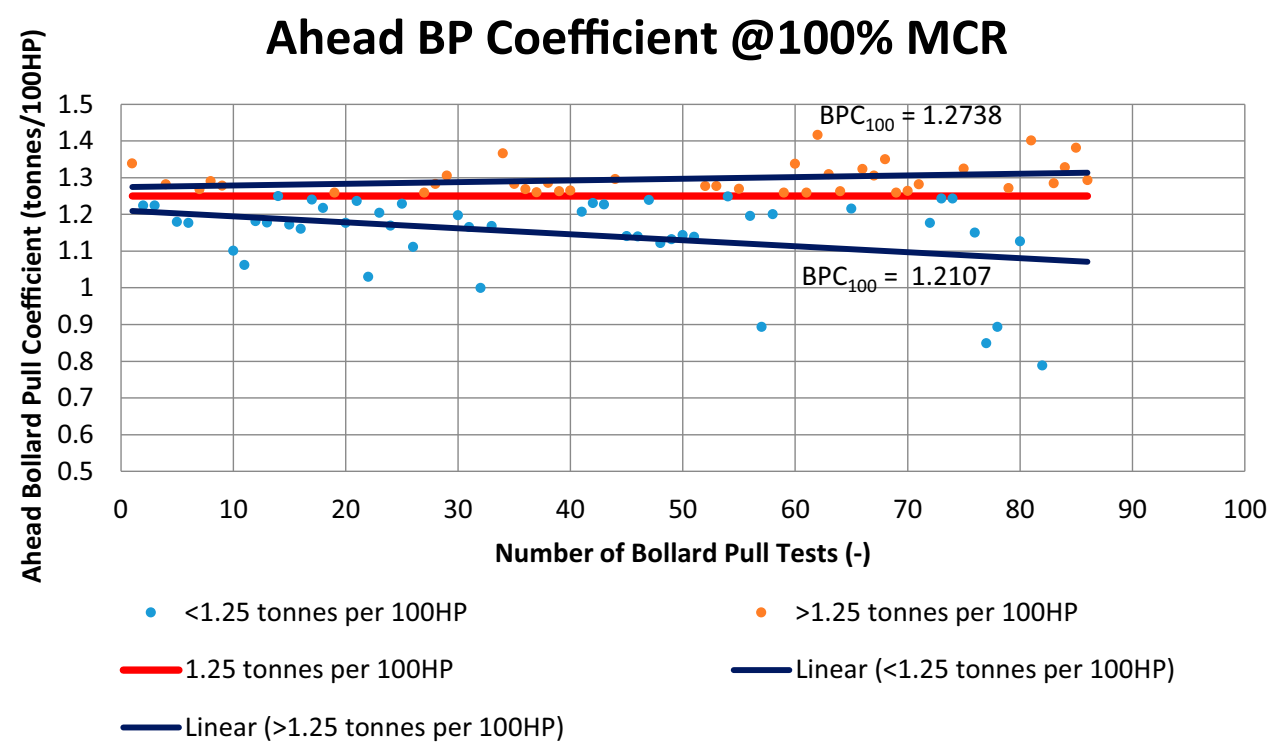

Fig. 14 Ahead bollard pull coefficient at 100\% MCR BHP 


\section{Ahead and Astern Bollard Pull @ 100\% MCR}

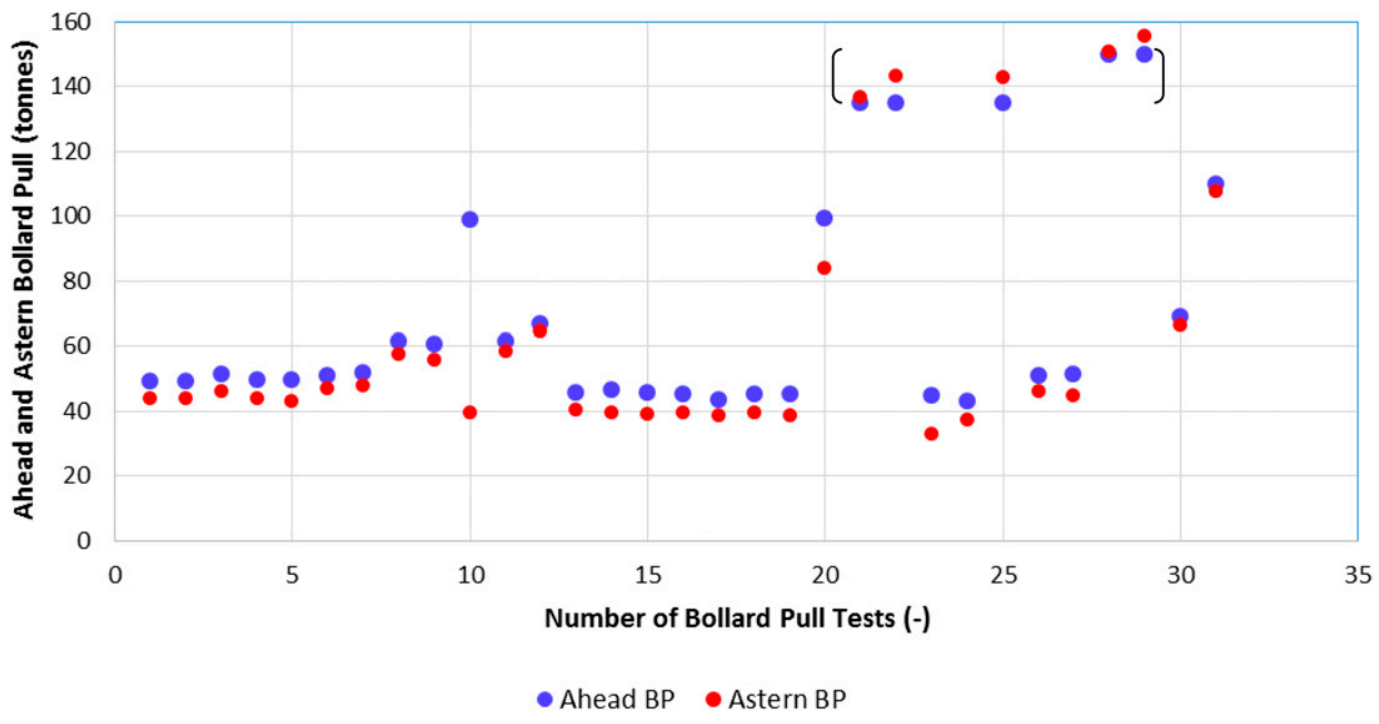

Fig. 15 Measured ahead and astern bollard pull at 100\% MCR BHP

Therefore, it is necessary to ensure a standardized procedure to provide a true (fact) value of BPT. In turn, it would be a fair functionality indicator for vessels which are required to undergo the BPT and trial.

The literature related to the subject also revealed the importance of conducting the BPT to obtain full-scale results. It would provide the ship owners with a form of verification during the delivery of the vessel.

As much as model-testing and the numerical solution can provide a kind of an answer, it is unable to simulate the full-scale environment. Therefore, it is safe to assume that BPT on a full-scale basis would then be most accurate to act as a functionality indicator for Tugs, AHTs, and AHTSVs.

It is also to be noted that there are several similarities and, more importantly, differences, in the directives/guidelines of the different classification societies. One significant difference would be the values of accuracy required by the classification societies for the calibration of the load cell.

If possible, and feasible, the standardized code of procedure should be recommended to classification societies. With the uniform application of proceedings during the conduct of bollard pull, it is possible to create a fair environment for the certification for all BPTs for all types of vessels.

Most importantly, operational safety can also be assured if the conduct of the BPT is carried out appropriately, on a yearly basis.

\section{Acknowledgment}

The present work benefited from the input of Mr. Ong Hing Hui, Past BEng student at Newcastle University, who has done his final

\section{Ratio of (Astern BP/Ahead BP) @ 100\% MCR}

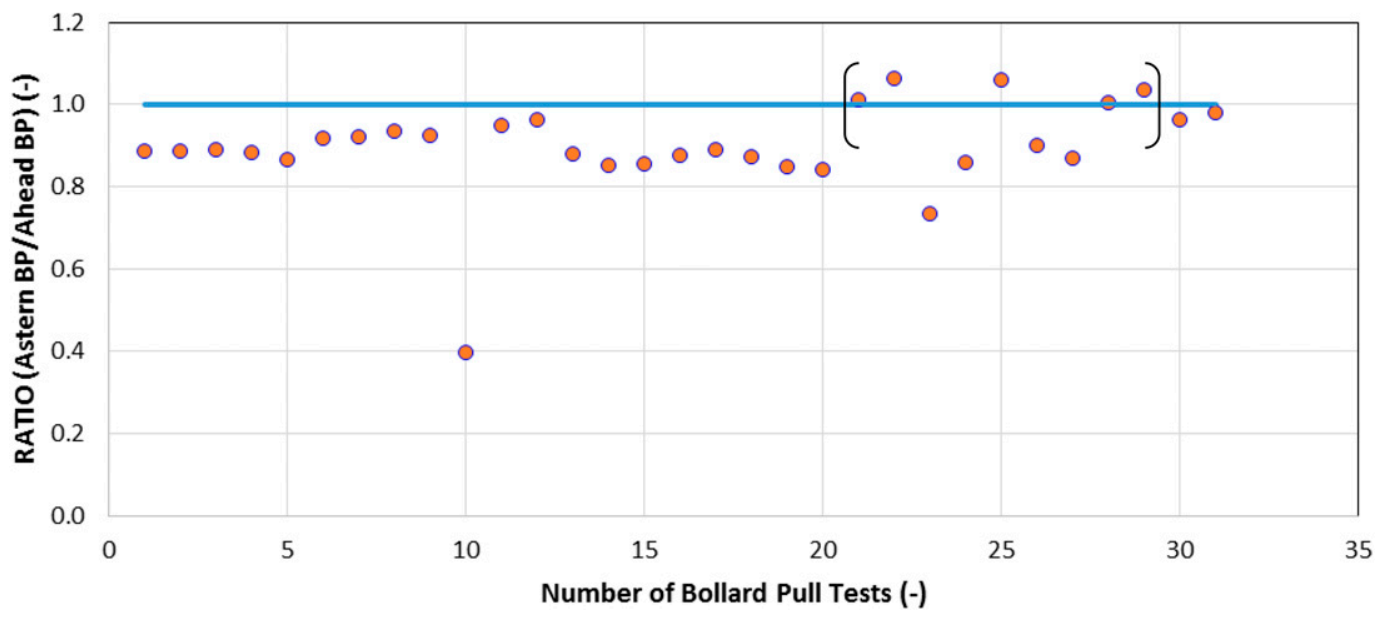

Fig. 16 Ratio of astern and ahead bollard pull at 100\% MCR BHP 
year project on a similar topic. The author is also grateful to Mr. Wei Gan, an ex-student of the University of Western Australia for compiling all the measured BPTs' data and produce initial graphs under the constant supervision of the author for almost 3 months. The author is also grateful to his classmate Mr. Makaraksha Saha helping to create the final graphs and review the article with some comments.

\section{References}

ABS. 2012 Part 5: Specialised Vessels and Services', Rules for Building and Classing; Steel Vessels Under 90 Meters (295 Feet) in Length, Houston, TX: American Bureau of Shipping.

BSRA. 1965 Code of Procedure for Bollard Trials of Tugs, Report No. 366, London, SE1, UK: The British Shipbuilding Research Association.

BV. 1986 Bollard Pull Measurement and Certification, Paris, France: Bureau Veritas.
Dev, A. K. 2013 Bollard Pull Test Result: Is it a fact or a gimmick or an illusion? What is then the reality? Public Lecture, Singapore.

DNV. 2011 Newbuildings Special Service and Type-Additional Class; Offshore Service Vessels, Tugs and Special Ships, Hovik, Norway: Det Norske Veritas.

GL Noble Denton. 2010 Guidelines for the Approval of Towing Vessels, Hovik, Norway: Det Norske Veritas.

IMO. 1998 Guidelines for Safe Ocean Towing, MSC/Circ.884, London SE1 7SR, UK: International Maritime Organization.

ITTC. 2011 'Propulsion/Bollard Pull Test', Recommended Procedures and Guidelines, Americas, Europe, Asia and Pacific: International Towing Tank Conference.

Lytewater, M. P. L. 2009 Kaplan Propeller. www.lytewatermarine.com/ commercial-marine-propellers/marine-propellers-kaplan.

Nielsen, J. R. 2010 Optimising Propulsion Systems for AHTS Vessels, Offshore \& Marine Technology, 2, 10-13.

RINA. 2011 Rules for the Certification of the Bollard Pull of Tugs, Genoa, Italy: Registro Italiano Navale.

SteERPRop. 2001 Bollard Pull Trial Code For Tugs with Steerprop Propulsors, Rauma, Finland: Steerprop Ltd.

Zahalka, C. P. 2012 Bollard Pull, Hamburg, Germany: Association of Hanseatic Marine Underwriters. 


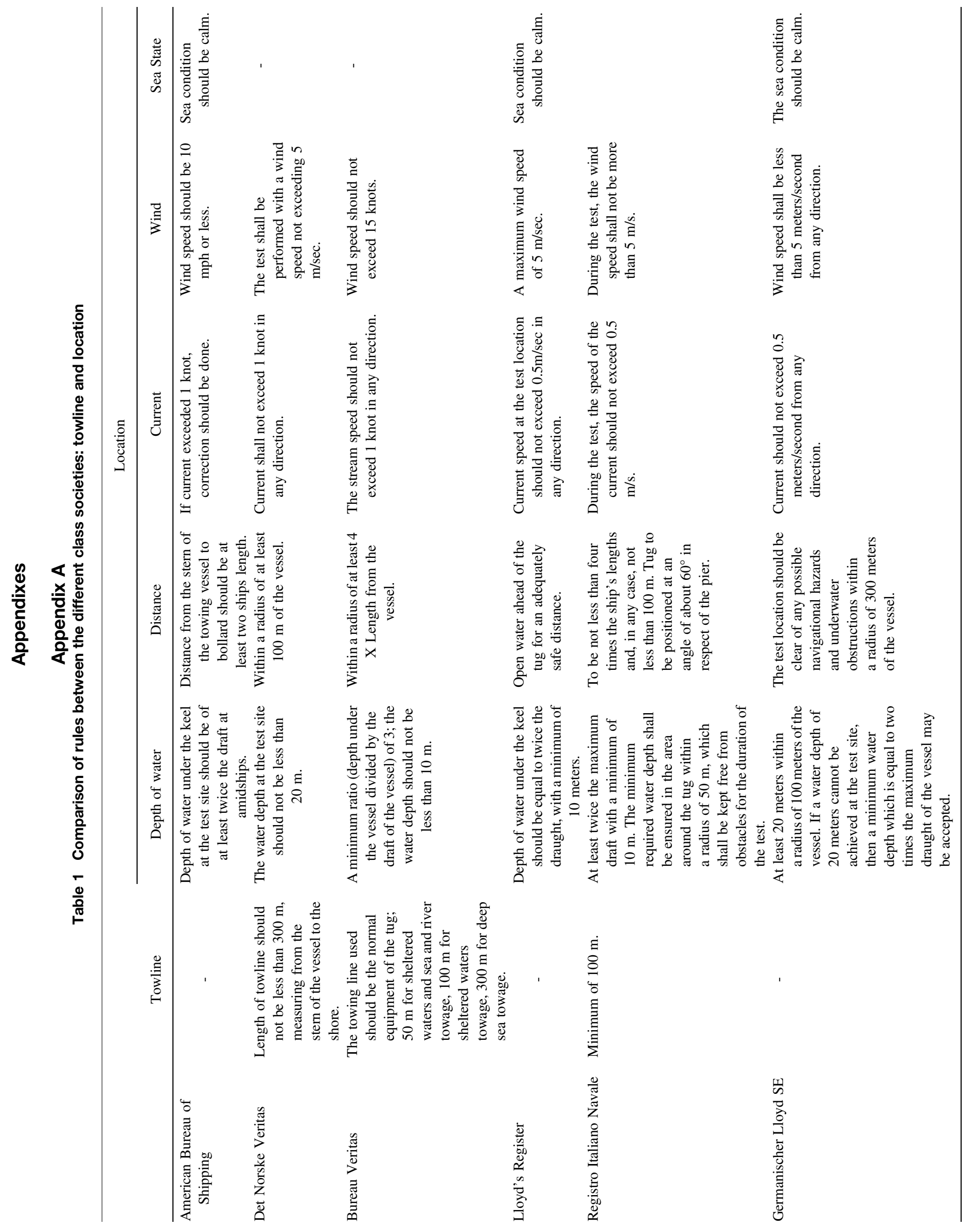


Table 2 Comparison of rules between the different class societies: vessel

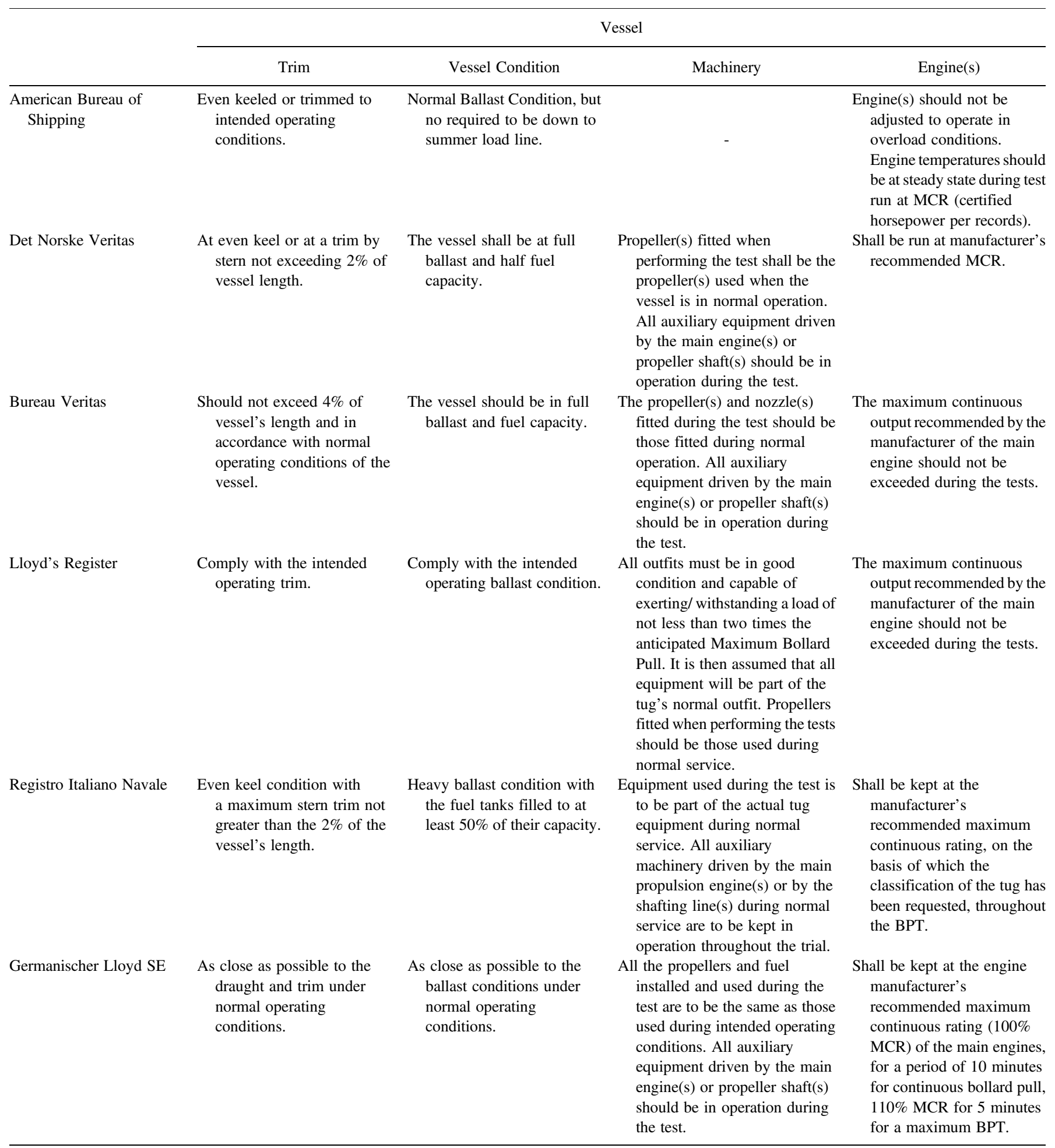


Table 3 Comparison of rules between the different class societies: instrumentation

\begin{tabular}{|c|c|c|c|c|c|}
\hline & \multicolumn{5}{|c|}{ Instrumentation } \\
\hline & Load Cell & Calibration & Continuous read-outs & Position of Load Cell & Communications \\
\hline $\begin{array}{l}\text { American Bureau } \\
\text { of Shipping }\end{array}$ & $\begin{array}{l}\text { Fitted with swivels and } \\
\text { torque insensitive. } \\
\text { Maximum scale } \\
\text { reading should be } \\
\text { a minimum or equal to } \\
\text { [Max. Cont. Total H.P. } \\
\text { X } 50 \text { (LBS.)] }\end{array}$ & $\begin{array}{l}\text { Should be calibrated } \\
\text { and suitable for use } \\
\text { in the horizontal } \\
\text { position. }\end{array}$ & - & $\begin{array}{l}\text { Should be located at the } \\
\text { ashore end of the tow } \\
\text { hawser. }\end{array}$ & $\begin{array}{l}\text { A two-way voice } \\
\text { communication } \\
\text { should be provided } \\
\text { between the vessel } \\
\text { and shore station }\end{array}$ \\
\hline Det Norske Veritas & $\begin{array}{l}\text { Load cell used for the test } \\
\text { shall be approved by } \\
\text { DNV }\end{array}$ & $\begin{array}{l}\text { Calibrated for at least } \\
\text { once a year. The } \\
\text { accuracy of the load } \\
\text { cell shall be } \pm 2 \% \\
\text { within a range of } \\
-10^{\circ} \mathrm{C} \text { to }+40^{\circ} \mathrm{C} \\
\text { and within the range } \\
\text { of } 25 \text { and } 200 \\
\text { tonnes tension. }\end{array}$ & $\begin{array}{l}\text { The instrument giving } \\
\text { a continuous read-out also } \\
\text { a recording instrument } \\
\text { recording the bollard pull } \\
\text { graphically as a function of } \\
\text { time shall both be } \\
\text { connected to the load cell. }\end{array}$ & $\begin{array}{l}\text { Load cell shall be fitted } \\
\text { between the eye of the } \\
\text { towline and the bollard. }\end{array}$ & $\begin{array}{l}\text { A communication } \\
\text { system shall be } \\
\text { established between } \\
\text { the vessel and the } \\
\text { person(s) } \\
\text { monitoring ashore, } \\
\text { by means of VHF or } \\
\text { telephone } \\
\text { connection. }\end{array}$ \\
\hline Bureau Veritas & $\begin{array}{l}\text { Other methods of } \\
\text { measurement for } \\
\text { instance based on the } \\
\text { readings on winch } \\
\text { equipment (tension } \\
\text { indicator, pressure } \\
\text { gauge) may be accepted } \\
\text { subject to compliance } \\
\text { with accuracy } \\
\text { requirements. }\end{array}$ & $\begin{array}{l}\text { The cumulated } \\
\text { accuracy of all the } \\
\text { measuring } \\
\text { equipment is } 5 \% \\
\text { within } \\
\text { a temperature range } \\
\text { of }-20^{\circ} \mathrm{C} \text { to }+40^{\circ} \mathrm{C}\end{array}$ & $\begin{array}{l}\text { Continuous read-outs and } \\
\text { a recording of the bollard } \\
\text { pull are recommended. If } \\
\text { not possible, readings are } \\
\text { taken every } 30 \text { seconds. }\end{array}$ & - & $\begin{array}{l}\text { Recommended to have } \\
\text { recording } \\
\text { equipment ashore, } \\
\text { and a reliable } \\
\text { telecommunication } \\
\text { system. }\end{array}$ \\
\hline Lloyd's Register & $\begin{array}{l}\text { Should produce } \\
\text { continuous readout in } \\
\text { numerical and } \\
\text { graphical form. The } \\
\text { instrument should be } \\
\text { calibrated before each } \\
\text { application by the } \\
\text { Society or any other } \\
\text { recognized authority. }\end{array}$ & $\begin{array}{l}\text { Expected accuracy to } \\
\text { be within } \pm 2 \% \text {. }\end{array}$ & $\begin{array}{l}\text { The recordings of the } \\
\text { dynamometer should be } \\
\text { coupled with the recordings } \\
\text { of the main engine output } \\
\text { and shaft revolutions. The } \\
\text { dynamometer could be of } \\
\text { the form of mechanical load } \\
\text { gauge or an electric load } \\
\text { cell. }\end{array}$ & $\begin{array}{l}\text { Incorporated within the } \\
\text { towing wire system, be } \\
\text { located at the shore line } \\
\text { or on the tug. }\end{array}$ & - \\
\hline $\begin{array}{l}\text { Registro Italiano } \\
\text { Navale }\end{array}$ & $\begin{array}{l}\text { The use of electric load } \\
\text { cell type measuring } \\
\text { instruments is } \\
\text { recommended insofar } \\
\text { as they can be } \\
\text { connected to the } \\
\text { recording equipment } \\
\text { easily }\end{array}$ & $\begin{array}{l}\text { Of not more than } \\
12 \text { months before } \\
\text { the date of the BPT. } \\
\text { In temperatures } \\
\text { between } 0 \text { and } \\
+40^{\circ} \mathrm{C} \text {. Maximum } \\
\text { deviation from the } \\
\text { nominal value is not } \\
\text { more than } \pm 2 \%\end{array}$ & $\begin{array}{l}\text { Shall be able to provide } \\
\text { a continuous reading of the } \\
\text { tug pull and record the } \\
\text { values measured either in } \\
\text { digital format or by means } \\
\text { of a graph. }\end{array}$ & $\begin{array}{l}\text { Connected directly to the } \\
\text { towline. Placed in } \\
\text { proximity to the towing } \\
\text { hook (on board) or to } \\
\text { the pier bollard } \\
\text { (ashore). }\end{array}$ & $\begin{array}{l}\text { Necessary to provide } \\
\text { an efficient two- } \\
\text { way } \\
\text { communication } \\
\text { system between the } \\
\text { tug and the shore } \\
\text { personnel } \\
\text { responsible for } \\
\text { monitoring the pull } \\
\text { measurements. }\end{array}$ \\
\hline $\begin{array}{l}\text { Germanischer } \\
\text { Lloyd SE }\end{array}$ & $\begin{array}{l}\text { The calibration certificate } \\
\text { of the load cell should } \\
\text { be provided prior the } \\
\text { test date. }\end{array}$ & $\begin{array}{l}\text { Calibration must be } \\
\text { less than } 6 \text { months } \\
\text { before the test. } \\
\text { Accuracy of } \pm 2 \% \\
\text { for the average } \\
\text { temperature } \\
\text { observed } \\
\text { throughout the test. }\end{array}$ & $\begin{array}{l}\text { An autographic recording } \\
\text { instrument that gives } \\
\text { a continuous read-out of the } \\
\text { bollard pull should be } \\
\text { connected to the load cell. } \\
\text { Otherwise, the bollard pull } \\
\text { is then the average value of } \\
\text { the subsequent readings, } \\
\text { recorded every } 20 \text { seconds } \\
\text { intervals over the test } \\
\text { period. }\end{array}$ & - & - \\
\hline
\end{tabular}




\section{Appendix B \\ BPT guidance checklist \\ Project number: click here to enter a number. Certificate number: click here to enter a number}

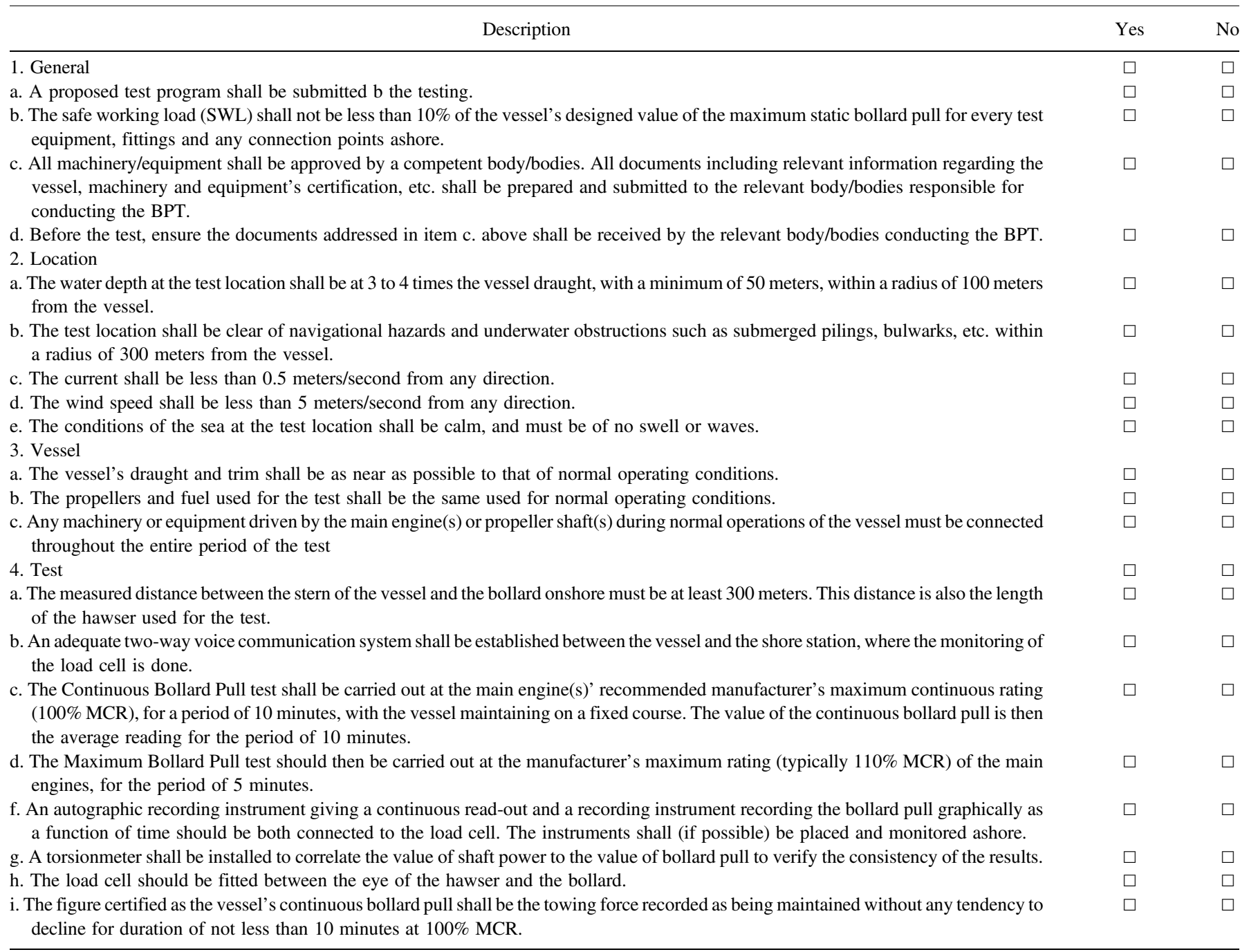

\section{Appendix C BPTR}

Project number: click here to enter a number. certificate number: click here to enter a number.

Choose an item. 'Enter Vessel Name."

This is to certify that the undersigned Marine Surveyor did on Click here to enter a date attend the Choose an item. "Enter Vessel Name.”, IMO No. Enter IMO number., of Enter Ship Owner(s) as the vessel stay afloat in the Enter Test Venue relative to a BPT and to report as follows:
The vessel's propulsion equipment consists of Enter No. of Engine (s)/Engine Maker. engine(s), Model Enter Model Number. developing a combined output of Enter output in B.H.P.B.H.P (Enter Output in kW. $\mathrm{kW}$ ) at Enter R.P.M. R.P.M. Each engine drives through a Enter Brand of Propulsion System. Model Enter Model of Propulsion System of Reduction Gear Ratio Enter Reduction Gear Ratio.

At the time of this BPT, there Choose Number of Surveyors. Surveyor(s) (Name of Surveyor) on the Choose Type of Vessel and Choose Number of Surveyors. Surveyor(s) (Name of Surveyor) with the Load Cell Operator.

The BPT was conducted at Start Time/ nd Time hours in the ahead direction and Start Time/End Time hours in the astern direction. The conditions for the bollard pull were as follows: 


\begin{tabular}{|c|c|c|c|}
\hline \multicolumn{2}{|l|}{ Environmental conditions } & \multicolumn{2}{|c|}{ Ship condition } \\
\hline Wind/Direction & Knots kts/Direction & Draught forward & Click here to enter text. $\mathrm{m}$ \\
\hline Current/Direction & Knots kts/Direction & Draught aft & Click here to enter text. $\mathrm{m}$ \\
\hline Water depth & $\begin{array}{l}\text { Click here to enter text. m } \\
\qquad \text { Equipment particulars }\end{array}$ & Draught amidships & Click here to enter text. $\mathrm{m}$ \\
\hline Main hawser ength & Click here to enter text. $\mathrm{m}$ & Breaking load & Click here to enter text. tonnes \\
\hline Spare hawser length & Click here to enter text. $\mathrm{m}$ & Breaking load & Click here to enter text. tonnes \\
\hline Winch rated pull & Click here to enter text. & Winch brake & Click here to enter text. \\
\hline
\end{tabular}

A Model Enter Model of Load Cell with Enter Load Range capacity, calibrated on Click here to enter a date was used. Enter Company for Indicator. provided a computerized indicator with recording/printing capabilities.

It is hereby certified that the vessel under the conditions described over, exerted a Continuous Bollard Pull of Enter Bollard Pull tonnes over a minimum period of 10 minutes. It is also certified that the Maximum Bollard Pull of Enter Bollard Pull tonnes over a period of 5 minutes.
The BPT was witnessed, and this report prepared without prejudice as to rights and/or interests of whom it may concern.

\section{$X$}

(Surveyor's Fulll Name)

Surveyor 


\section{Appendix - D}

\section{BOLLARD PULL TEST DATA FORM}

Project Number: Click here to enter a number. Certificate Number: Click here to enter a number.

Choose an item. "Enter Vessel Name."

For Surveyor with Load Cell

\begin{tabular}{|l|l|}
\hline \multicolumn{2}{|c|}{ Bollard Pull Test Location and Personnel Data } \\
\hline Test Date & Click here to enter a date. \\
\hline Location & \\
\hline Vessel Name & \\
\hline Marine Surveyor & \\
\hline Others in Attendance & \\
\hline \multicolumn{2}{|c|}{ General Comments } \\
\hline \multicolumn{2}{|c|}{} \\
\hline
\end{tabular}

\begin{tabular}{|l|l|}
\hline \multicolumn{2}{|c|}{ Load Cell Data } \\
\hline Load Cell Manufacturer's Name & \\
\hline Load Cell Model/Type & \\
\hline Load Cell Last Calibration Date & \\
\hline Recording Device (Computer) & \\
\hline Recording Device Manufacturer/Model/Type & \\
\hline Load Cell Operator's Name and Company & \\
\hline
\end{tabular}

Comments

\begin{tabular}{|c|c|c|c|c|}
\hline \multicolumn{5}{|c|}{ Bollard Pull Test Data } \\
\hline \multicolumn{5}{|c|}{ Identify and Highlight the Maximum Pull Sustained for 5 Minutes. } \\
\hline \multirow{2}{*}{$\begin{array}{l}\text { Time of Day (Hour, } \\
\text { Minutes, Seconds) } \\
\end{array}$} & \multicolumn{3}{|c|}{ Bollard Pull (Tonnes) } & \multirow{2}{*}{$\begin{array}{c}\text { Mean Pull for Previous } \\
10 \text { Readings } \\
\end{array}$} \\
\hline & Maximum & Minimum & Mean & \\
\hline \multicolumn{5}{|c|}{ Bollard Pull Test Data } \\
\hline \multirow{2}{*}{$\begin{array}{l}\text { Time of Day (Hour, } \\
\text { Minutes, Seconds) }\end{array}$} & \multicolumn{3}{|c|}{ Bollard Pull (Tonnes) } & Mean Pull for Previous \\
\hline & Maximum & Minimum & Mean & 10 Readings \\
\hline
\end{tabular}

\section{REMARKS}

\begin{tabular}{|c|l|}
\hline$\square$ & $\begin{array}{l}\text { The load cell used for the test had/had not* been calibrated within the preceding } 12 \text { months by a certified testing } \\
\text { laboratory. The last certificate was/was not* available for review at time of the bollard pull test. }\end{array}$ \\
\hline$\square$ & The load cell provided/did not provide* a continuous readout. \\
\hline$\square$ & A device for recording the bollard pull graphically, as a function of the time was/was not connected* to the load cell. \\
\hline$\square$ & 2-Way voice communication was maintained between the dock and tug during the course of this test. \\
\hline$\square$ & $\begin{array}{l}\text { During the test, there was one Surveyor located in the vessel's engine room and one Surveyor was located on the dock in } \\
\text { a position to view the load cell indications. }\end{array}$ \\
\hline
\end{tabular}

\begin{tabular}{|l|l|l|l|}
\hline \multicolumn{3}{|c|}{ Surveyor with Load Cell: } & \\
\hline Print Name: & & & \\
\hline Company: & & \\
\hline
\end{tabular}

\begin{tabular}{|l|l|l|l|}
\hline \multicolumn{3}{|c|}{ Load Cell Operator: } \\
\hline Print Name: & & & \\
\hline Company: & & & \\
\hline
\end{tabular}




\section{Appendix - E}

\section{BOLLARD PULL TEST DATA FORM}

Project Number: Click here to enter a number. Certificate Number: Click here to enter a number.

Choose an item. "Enter Vessel Name."

For Surveyor Onboard Vessel

\begin{tabular}{|l|l|}
\hline \multicolumn{2}{|c|}{ Bollard Pull Test Location and Personnel Data } \\
\hline Test Date & Click here to enter a date. \\
\hline Test Location & \\
\hline Vessel Name & \\
\hline Marine Surveyor & \\
\hline
\end{tabular}

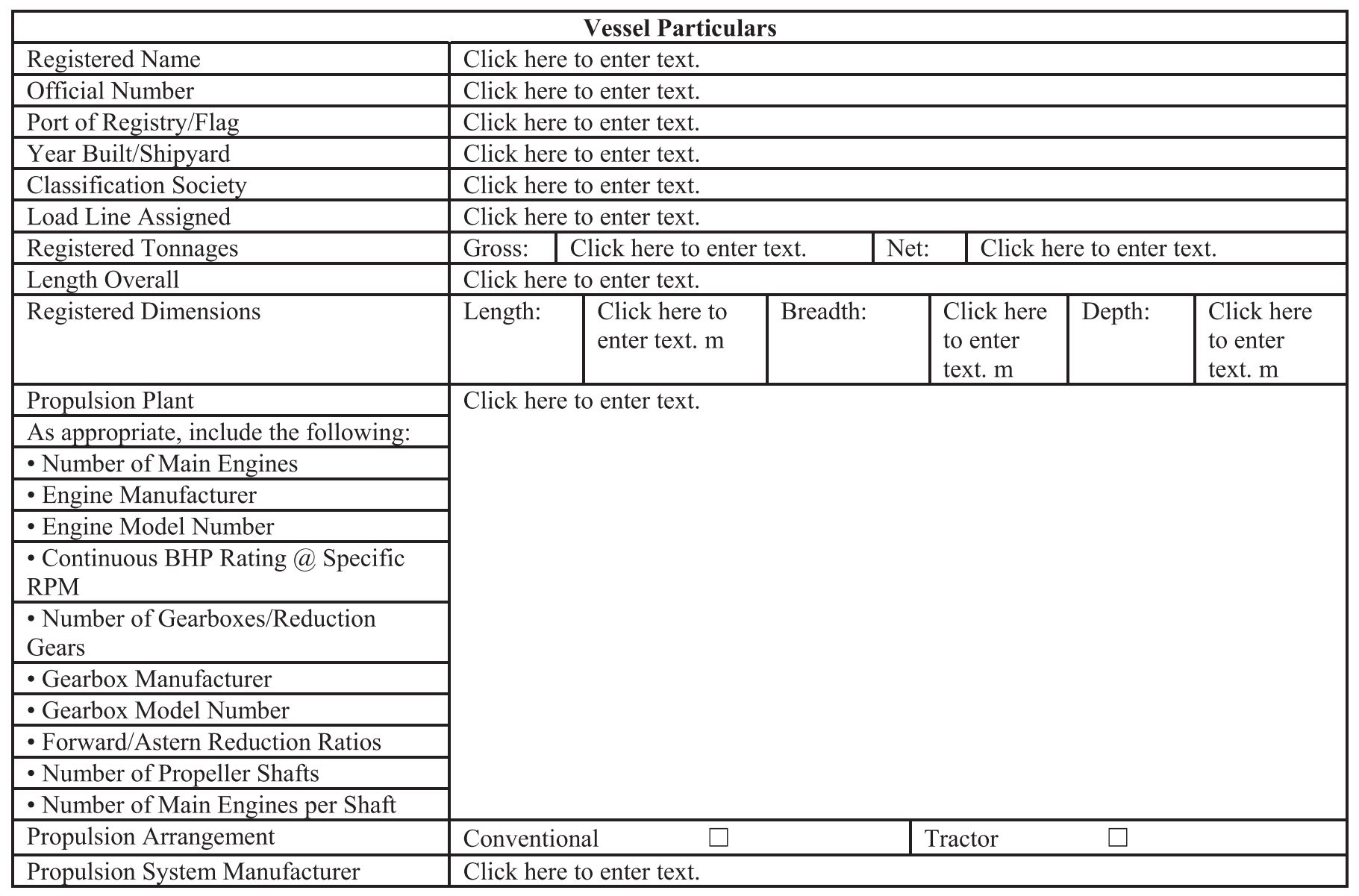




\begin{tabular}{|l|l|l|l|l|l|l|}
\hline Propeller(s) used for Test & Diameter: & $\begin{array}{l}\text { Click here to } \\
\text { enter text. } \mathrm{m}\end{array}$ & Pitch: & $\begin{array}{l}\text { Click here to } \\
\text { enter text. } \mathrm{m}\end{array}$ & No. of Blades: & \\
\hline
\end{tabular}

\section{Comments Pertaining to Vessel / Vessel Personnel}

\begin{tabular}{|c|c|c|c|c|}
\hline \multicolumn{5}{|c|}{ Bollard Pull Test Situation } \\
\hline Water Depth@,Test Site & \multicolumn{4}{|c|}{ Click here to enter text. $\mathrm{m}$} \\
\hline Water Current @, Test Site (Knots) & \multicolumn{4}{|c|}{ Click here to enter text. Knots } \\
\hline Wind Direction / Speed (m/s) & \multicolumn{4}{|c|}{ Click here to enter text at Click here to enter text. $\mathrm{m} / \mathrm{s}$} \\
\hline Approximate Air Temperature & \multicolumn{4}{|c|}{ Click here to enter text. ${ }^{\circ} \mathrm{C}$} \\
\hline Vessel's Drafts & Forward: & Click here to enter text. $\mathrm{m}$ & Aft: & Click here to enter text. $\mathrm{m}$ \\
\hline Towing Hawser & \multicolumn{4}{|c|}{ Size and Material. } \\
\hline
\end{tabular}

\begin{tabular}{|c|c|c|c|c|c|c|}
\hline \multicolumn{7}{|c|}{ Bollard Pull Test - Vessel Operations Data } \\
\hline Main Engine Data & \multicolumn{2}{|c|}{ Port Engine: } & \multicolumn{2}{|c|}{ Center Engine: } & \multicolumn{2}{|c|}{ Starboard Engine: } \\
\hline $\begin{array}{l}\text { Max Continuous RPM - } \\
\text { Rated/During Test }\end{array}$ & \multicolumn{2}{|c|}{ / } & \multicolumn{2}{|c|}{ / } & \multicolumn{2}{|c|}{ / } \\
\hline \multicolumn{7}{|l|}{$\begin{array}{l}\text { Rated Continuous BHP@ Enter } \\
\text { RPMRPM }\end{array}$} \\
\hline \multicolumn{7}{|l|}{ Over speed RPM Settings } \\
\hline Max. Cooling Water Temperature & In: ${ }^{\circ} \mathrm{c}$ & Out: ${ }^{\circ} \mathrm{c}$ & In: ${ }^{\circ} \mathrm{c}$ & Out: ${ }^{\circ} \mathrm{c}$ & In: ${ }^{\circ} \mathrm{c}$ & Out: ${ }^{\circ} \mathrm{c}$ \\
\hline Exhaust Air Temperature & \multicolumn{2}{|c|}{${ }^{\circ} \mathrm{C}$} & \multicolumn{2}{|c|}{${ }^{\circ} \mathrm{C}$} & \multicolumn{2}{|c|}{${ }^{\circ} \mathrm{c}$} \\
\hline \multicolumn{7}{|l|}{ Reduction Gear Ratio } \\
\hline \multicolumn{7}{|l|}{ Reported Propeller Material } \\
\hline \multicolumn{7}{|l|}{ Reported No. of Propeller Blades } \\
\hline
\end{tabular}

\section{REMARKS}

\begin{tabular}{|c|l|}
\hline$\square$ & $\begin{array}{l}\text { The test was carried out with the vessel's trim and/or displacement which correspond to the relevant Load Line } \\
\text { requirements and/or Letter of Stability provided. }\end{array}$ \\
\hline$\square$ & Auxiliary equipment (i.e., pumps, etc.) \\
\hline$\square$ & $\begin{array}{l}\text { The propellers fitted on the vessel during the test are the same as those reportedly used when the vessel is in normal } \\
\text { operation. }\end{array}$ \\
\hline$\square$ & Water depth under the keel was twice the vessel's depth at midship. \\
\hline$\square$ & Water current did not exceed 1.0 knot. \\
\hline$\square$ & Wind Speed did not exceed 10 Miles per Hour. \\
\hline$\square$ & Towline Length was at least twice the length of the vessel from stern/bow to fixed bollard. \\
\hline$\square$ & 2-Way voice communication was maintained between the dock and vessel throughout the entire test. \\
\hline
\end{tabular}

\begin{tabular}{|l|l|l|l|}
\hline \multicolumn{3}{|c|}{ Surveyor on board the Vessel: } \\
\hline Print Name: & & & \\
\hline Company: & & & \\
\hline
\end{tabular}

